\title{
BASE FERTILIZATION COMPENSATION AS A METHODOLOGY FOR COMPARISON OF CONTAINERS VOLUMES
}

\author{
Rodolfo Soares de Almeida ${ }^{1^{*}}$, Tatiana Arantes Afonso $\mathrm{Vaz}^{2}$, Maria José da Silva Ventura ${ }^{3}$, Antonio Claudio \\ Davide $^{4}$, Lucas Amaral de Melo ${ }^{5}$, Gabriel Assis-Pereira ${ }^{6}$ \\ 1*Universidade Federal de Lavras, Departamento de Ciências Florestais, Lavras, Minas Gerais, Brasil - rodolfoflorestal@ gmail.com \\ ${ }^{2}$ Universidade Federal do Triângulo Mineiro, Divisão de Gestão dos Laboratórios, Iturama, Minas Gerais, Brasil - \\ tatiana.arantes@gmail.com \\ ${ }^{3}$ Instituto Federal de Educação, Ciência e Tecnologia de Rondônia, Colorado do Oeste, Rondônia, Brasil - \\ mariaventuradasilva27@yahoo.com.br \\ ${ }^{4}$ Universidade Federal de Lavras, Departamento de Ciências Florestais, Lavras, Minas Gerais, Brasil - acdavide@dcf.ufla.br \\ ${ }^{5}$ Universidade Federal de Lavras, Departamento de Ciências Florestais, Lavras, Minas Gerais, Brasil - lucas.amaral@ufla.br \\ ${ }^{6}$ Escola Superior de Agricultura Luiz de Queiroz, Universidade de São Paulo, Departamento de Ciências Florestais, Piracicaba, São Paulo, \\ Brasil - gabriel_assispereira@hotmail.com
}

Received for publication: 31/08/2020 - Accepted for publication: 09/04/2021

\begin{abstract}
Resumo
Compensação da adubação de base como metodologia para comparação de volume de recipientes. A atual metodologia de comparação de capacidade volumétrica de recipientes não possibilita diferenciar os efeitos causados pela maior concentração de fertilizantes, disponíveis por volume de recipiente, do real efeito do espaço de crescimento e da fertilização. A compensação de adubação visa corrigir o efeito da concentração de fertilizantes, garantindo a mesma proporção de adubação em diferentes capacidades volumétricas de recipientes, possibilitando ser uma nova metodologia para produção de mudas florestais. A proposta metodológica foi aplicada na produção de mudas de Handroanthus ochraceus, testando duas capacidades volumétricas, 55 e $115 \mathrm{~cm}^{3}$, de recipientes, do tipo tubete e seis doses de adubo de liberação controlada, a saber: 0,$19 ; 0,24 ; 0,30 ; 0,40 ; 0,51$ e $0,63 \mathrm{~g} /$ tubete em delineamento inteiramente casualizado com quatro repetições. Foram avaliadas a altura e diâmetro do coleto, quinzenalmente até os 150 dias após a semeadura e a matéria seca da parte aérea e radicular. Os resultados demonstram que independente da capacidade volumétrica do recipiente, as maiores doses de adubo resultaram em maiores características morfológicas. Logo, o efeito responsável pelo crescimento diferencial entre a capacidade volumétrica dos recipientes, normalmente atribuído ao maior espaço disponível para o desenvolvimento radicular, na realidade é atribuído a maior disponibilidade de nutrientes, o qual a compensação de adubação visa manter constante. Conclui-se que a utilização da compensação da fertilização de base demonstrou ser eficiente para as comparações entre capacidades volumétricas de recipiente.
\end{abstract}

Palavras-chave: Produção de mudas florestais, adubos de liberação lenta, tubetes, qualidade de mudas.

Abstract
The current methodology for comparing the volumetric capacity of containers does not make it possible to
differentiate the effects caused by the higher concentration of fertilizers, available by volume of container, from
the real effect of the growth space and fertilization. The fertilization compensation aims to correct the effect of
the concentration of fertilizers, guaranteeing the same proportion of fertilization in different volumetric
capacities of containers, making it possible to be a new methodology for the production of forest seedlings. The
methodological proposal was applied to the production of Handroanthus ochraceus seedlings, testing two
volumetric capacities, 55 and $115 \mathrm{~cm}^{3}$, of containers, of the tube type and six doses of controlled release
fertilizer, namely: $0.19 ; 0.24 ; 0.30 ; 0.40 ; 0.51$ and $0.63 \mathrm{~g} /$ tube in a completely randomized design with four
replications. The height and diameter of the collection were evaluated biweekly up to 150 days after sowing
and the dry matter of the aerial and root parts. The results demonstrate that regardless of the volumetric capacity
of the container, the highest doses of fertilizer resulted in greater morphological characteristics. Therefore, the
effect responsible for the differential growth between the volumetric capacity of the containers, normally
attributed to the greater space available for root development, is actually attributed to the greater availability of
nutrients, which the fertilization compensation aims to keep constant. It was concluded that the use of basic
fertilization compensation proved to be efficient for comparisons between volumetric container capacities.
Keywords: Production of forest seedlings, slow release fertilizers, tubes, quality of seedlings.

\section{INTRODUCTION}

In the production of forest species seedlings for commercial projects and use in restoration projects, the most used containers are polyethylene plastic bags and polypropylene tubes. There are several dimensions of these containers on the market. However, as a general recommendation, Davide and Faria (2008) do not advise containers with a volume greater than $1 \mathrm{dm}^{3}$ for plastic bags and greater than $180 \mathrm{~cm}^{3}$ for tubes. For both cases, due to the high cost of the container, intense consumption of substrate and other aspects related to production, transportation costs, and planting problems, even due to long root systems. Therefore, the choice of container 
volume considers the production objective and the species, which have different needs regarding the volume capacity of suitable containers for their development. However, several authors, such as Almeida et al. (2014); Figueiró et al. (2017); Melo et al. (2018); Lima Filho et al. (2019), demonstrated gains in growth and quality of forest seedlings with the use of larger volumetric containers.

For the proper development of seedlings, both in height, diameter and biomass production, it is essential that the substrate is chemically balanced (VIEIRA et al., 2019). The base fertilization of the substrate is necessary to meet the nutritional demands of the seedlings and must supplement the nutrients already available in the substrate (SILVA et al., 2019). Controlled release fertilizers (FLC) are characterized by continuously providing nutrients, thus reducing the cost of production, and are increasingly used in forest nurseries (NAVROSKI et al., 2016; FERRARI et al., 2016).

However, the base fertilization of the substrates happens at the mixing of components, in the proportion of $\mathrm{kg}$ of fertilizer per $\mathrm{m}^{3}$ of the substrate, resulting in tubes with greater volumetric capacity have greater availability of nutrients compared to those with lower volume, although the concentration of nutrients per volume of the substrate does not change (DAVIDE; FARIA, 2008; GOMES; PAIVA, 2011). Therefore, using this methodology, it is not possible to isolate the effect of the capacity of the tube and the greater availability of nutrients.

Thus, this work aimed to verify the use of base fertilization compensation as a methodology to isolate the effect of container volume capacity on the production of forest seedlings.

\section{MATERIAL AND METHODS}

Handroanthus ochraceus (Cham.) Mattos is a native to the Brazilian flora belonging to the Bignoniaceae family, popularly known as ipê-do-cerrado. This species was used as a model for this work, as it presents a wide dispersion throughout Brazil and slow growth characteristic of climax species (LORENZI, 2002).

The experiment was carried out from September to May in a forest nursery in the municipality of Lavras, Minas Gerais, located at latitude $21^{\circ} 14$ 'S , longitude $45^{\circ} 00 \mathrm{~W}$, at an altitude of $918 \mathrm{~m}$ and with climate type CWa, according to the classification of Koppen (DANTAS et al., 2007).

For the production of seedlings were used two sizes of polypropylene tubes with a capacity of 55 and 115 $\mathrm{cm}^{3}$ on suspended benches. The substrate composition was $10 \%$ vermiculite, $20 \%$ tanned and sieved manure, $30 \%$ carbonized rice husk, and $40 \%$ coconut fiber. All components were mixed at a concrete mixer.

As base fertilization, Osmocote ${ }^{\circledR}$ brand slow-release fertilizer (FLL) was used, composed of nitrogen $(\mathrm{N})$, phosphorus $(\mathrm{P} 2 \mathrm{O} 5)$ and potassium $(\mathrm{K} 2 \mathrm{O})$ in the proportion of 15:09:12, plus 1.3\% magnesium $(\mathrm{Mg}), 0.05 \%$ copper $(\mathrm{Cu}), 0.06 \%$ manganese $(\mathrm{Mn}), 0.02 \%$ molybdenum $(\mathrm{Mo}), 6 \%$ sulfur $(\mathrm{S})$ and $0.46 \%$ iron $(\mathrm{Fe})$, with release of 5-6 months.

The doses of basic fertilization used were $0.19 ; 0.24 ; 0.30 ; 0.40 ; 0.51$ and $0.63 \mathrm{~g}$ for each tube size. To ensure nutritional compensation, $55 \mathrm{dm}^{3}$ tubes were filled with substrates containing $3.50 ; 4.50 ; 5.50 ; 7.32 ; 9.41$, and $11.50 \mathrm{~kg}$ of fertilizer per $\mathrm{m}^{3}$ of the substrate, and those of $115 \mathrm{~cm}^{3}$ filled with $1.67 ; 2.15 ; 2.63 ; 3.50 ; 4.50$ and 5.50 respectively. The filling of the tubes happened manually, performing the compaction to ensure their proper filling.

The experiment was a completely randomized design (DIC), in a 2 x 6 factorial scheme, with two sizes of tubes, one with a volume capacity of $55 \mathrm{~cm}^{3}$ and the other of $115 \mathrm{~cm}^{3}$ and six doses of fertilizers. That is: 0.19 ; $0.24 ; 0.30 ; 0.40 ; 0.51$ and $0.63 \mathrm{~g} /$ tube, with four replications and 36 plants per plot.

The sowing was manual and direct on the tube with one seed per container and then covered with a $50 \%$ mesh shade net, remaining under this condition for 20 days after germination (DAG). A thinning, performed on the 30th DAG, following the methodology described by Davide and Faria (2008). The density of seedlings was reduced at 75th DAG, leaving 192 seedlings $/ \mathrm{m}^{2}$ throughout the experiment. Irrigation, carried out by microsprinklers located at the height of $1.70 \mathrm{~m}$ and with a spacing of $9 \mathrm{~m}^{2}$, with guaranteeing a uniformity coefficient of water distribution of $93 \%$, and flow of $60 \mathrm{~L} \mathrm{~h}-1$, four times a day, happens at 8:15;12:15; 14:15 and 17:15, lasting five minutes each, enough to moisten the substrate for visual observation and so that the occurrence of seedling wilt is not noticeable. We consider that the water factor was constant between the analyzed containers because the water blade was constant throughout the experimental area, and tubes of different sizes have an opening in the upper section proportional to their volumetric capacity, since, for each irrigation performed, the amount of water per volumetric unit of the substrate is very close between the two tubes.

The evaluations of the seedlings, height $(\mathrm{H})$, and diameter of the stem (DC) were carried out every 15 days, from $60^{\circ} \mathrm{DAG}$, recording the average of 16 central seedlings in each plot. The height was considered by the distance between the base of the substrate to the apical bud, measured with the aid of a graduated ruler. The diameter of the collar was quantified using a digital caliper measured at the level of the substrate. The destructive analysis happened on the 150th day of DAG when the seedlings were considered suitable for field planting, thus 
ending the nursery cycle. Shoot dry matter (MSPA), root dry matter (MSR), and total dry matter (TSM) were evaluated using the average mass of eight seedlings from each plot. They were previously placed in paper bags, in an oven at $70^{\circ} \mathrm{C}$, with forced air circulation, until they reached a constant mass. The quality of the seedlings was evaluated by the H/DC ratio, the MSPA/MSR ratio, and the Dickson quality index (DQI).

The data passed the Shapiro Wilk normality test and, when there was no normality $(\mathrm{p}<0.05)$, they were converted to $\log 10(\mathrm{X})$. Normalized data were analyzed using analysis of variance (ANOVA), and when there was a difference between treatments, regression analyzes were performed.

\section{RESULTS}

The growth curves in height and diameter of the stem of the seedlings of Handroanthus ochraceus showed linear behavior during the $150 \mathrm{DAG}$, for both tube sizes in which they were produced and under the different doses of fertilization tested (Figure 1). Fertilizer doses $0.40 ; 0.51 ; 0.63 \mathrm{~g} /$ tube allowed superior increases in height and diameter in the seedlings over time, making it possible to distinguish the growth curves for both characteristics since the 60th DAG.

The heights did not vary in terms of the volumetric capacity of the tube at 150 DAG. Recipients with 55 $\mathrm{cm}^{3}$ obtained greater diameter values compared to those achieved by the seedlings produced in those of $115 \mathrm{~cm}^{3}$ (Figure 1). The treatments with the lowest doses of fertilization did not guarantee the same growth pattern, remaining always below throughout the seedling production process.
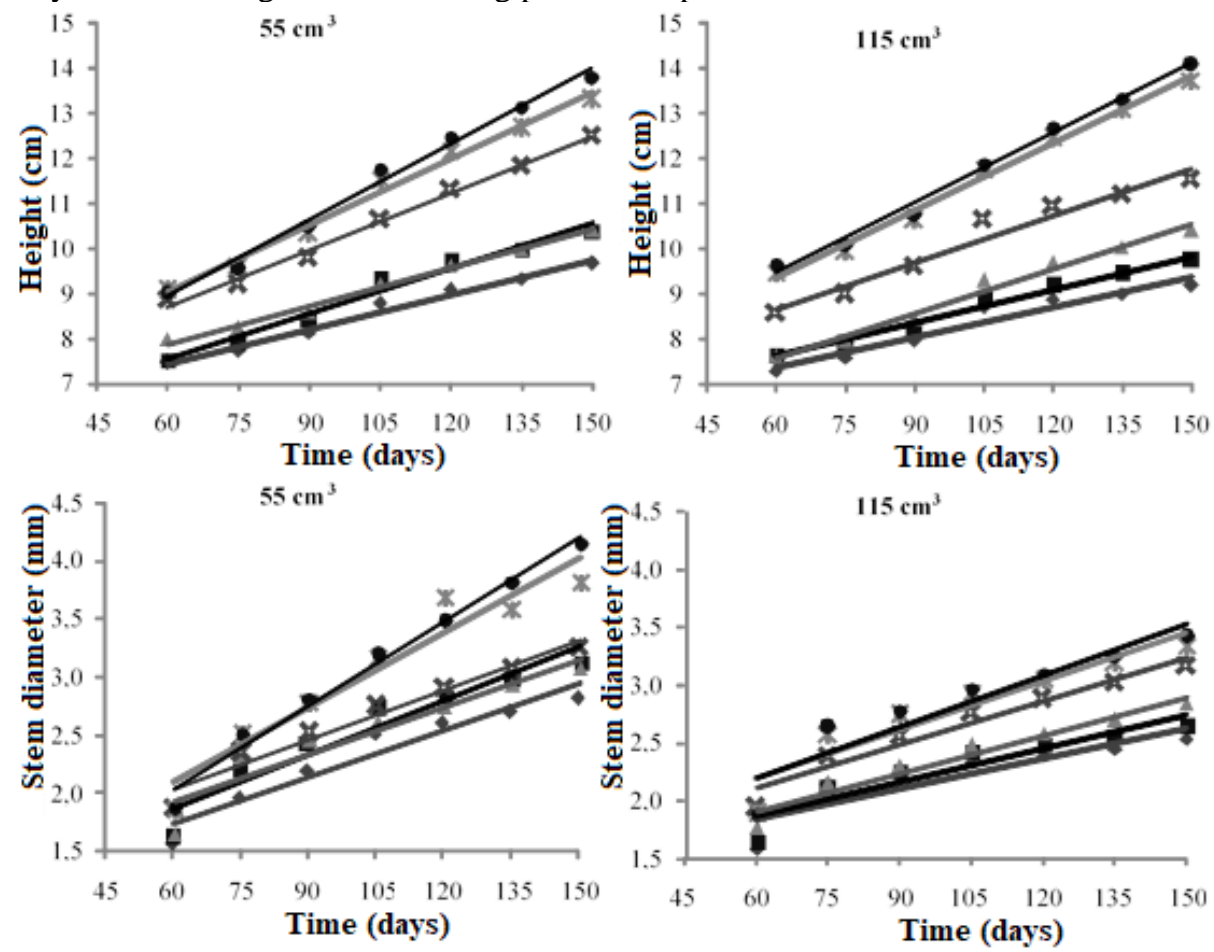

Doses ( $\mathrm{g} /$ tube )

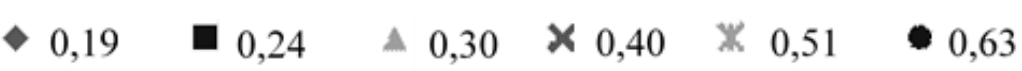

Figure 1. Growth in height and diameter of Handroanthus ochraceus seedlings, from 60 to 150 days after germination, produced in tubes with volumetric capacity of 55 and $115 \mathrm{~cm}^{3}$ with different doses of fertilizer, formulation 15: 09: 12, per tube.

Figura 1. Crescimento em altura e diâmetro do coleto das mudas de Handroanthus ochraceus, dos 60 aos 150 dias após germinação, produzidas em tubetes com capacidade volumétrica de 55 e $115 \mathrm{~cm}^{3}$ com diferentes doses de fertilizante, formulação15:09:12, por tubete.

There was a significant interaction between the volumetric capacity of the tube and the dose of fertilizer tested. This interaction was evidenced by the height $(\mathrm{H})$ and all quality parameters of the seedlings, H/DC, MSPA/MSR, and DQI, as shown in Table 1. For the other characteristics evaluated in the seedlings, DC, MSPA and MSR, there was no evidence of significant interaction between the factors, only varying within them. 
Table 1. Summary of variance analysis for nutritional compensation of six doses of fertilizer and two volumes of tubes for Handroanthus ochraceus seedlings at 150 days after germination.

Tabela 1. Resumo da análise de variância para compensação nutricional de seis doses de adubação de base e duas capacidades volumétricas de tubetes, para mudas de Handroanthus ochraceus, aos 150 dias após a germinação.

\begin{tabular}{|c|c|c|c|c|c|c|c|c|}
\hline \multirow[b]{2}{*}{ Source of Variation } & \multirow[b]{2}{*}{ D.F. } & \multicolumn{7}{|c|}{ Mean square } \\
\hline & & $\mathbf{H}$ & DC & H/DC & MSPA & MSR & $\begin{array}{c}\text { MSPA/ } \\
\text { MSR }\end{array}$ & DQI \\
\hline Dose (D) & 5 & $2.965^{*}$ & $124.27^{*}$ & $5.93^{*}$ & $56.45^{*}$ & $1.368^{*}$ & $8.066^{*}$ & $6.750^{*}$ \\
\hline Tube (T) & 1 & $0.849^{*}$ & $6.78^{*}$ & $0.39^{*}$ & $2.48^{*}$ & $0.762^{*}$ & $0.560^{*}$ & $2.450^{*}$ \\
\hline $\mathbf{D} \mathbf{x} \mathbf{T}$ & 5 & $0.073^{*}$ & $0.01^{\mathrm{ns}}$ & $3.10^{*}$ & $0.29^{\mathrm{ns}}$ & $0.005^{\mathrm{ns}}$ & $0.927^{*}$ & $0.174^{*}$ \\
\hline Residue & 24 & 0.006 & 0.27 & 0.40 & 0.10 & 0.014 & 0.083 & 0.056 \\
\hline Mean & & 11.96 & 3.25 & 3.69 & 0.99 & 1.60 & 0.66 & 0.61 \\
\hline CV $(\%)$ & & 7.31 & 16.05 & 17.13 & 32.43 & 38.98 & 43.72 & 38.47 \\
\hline
\end{tabular}

Values followed by “*” indicate a significant effect at 5\% probability by the F test, while values followed by "ns" indicate a non-significant effect. G.L.: Degrees of freedom; CV: Experimental coefficient of variation.

Figures 2 and 3 show the characteristics evaluated as a function of the base fertilization rates and the volumetric capacity of the tubes. The regressions indicated a maximum point for the H/DC ratio of $0.43 \mathrm{~g}$ of Osmocote ${ }^{\circledR}$ for 15:09:12 formulation and tubes with $55 \mathrm{~cm}^{3}$ (Figure 2C). The other characteristics evaluated followed a positive linear regression trend, with a coefficient of determination $\mathrm{r}^{2}$ ranging from 0.82 to 0.99 .

Seedlings produced in tubes with a volumetric capacity of $55 \mathrm{~cm}^{3}$ had larger stem diameters, larger root dry mass, and a higher Dickson quality index. For seedlings produced in recipients with a volumetric capacity of $115 \mathrm{~cm}^{3}$, the values were similar for $\mathrm{H}$ and MSPA. The ratios H/DC and MSPA/MSR seedlings showed superior growth when were used tubes with a volumetric capacity of $115 \mathrm{~cm}^{3}$.
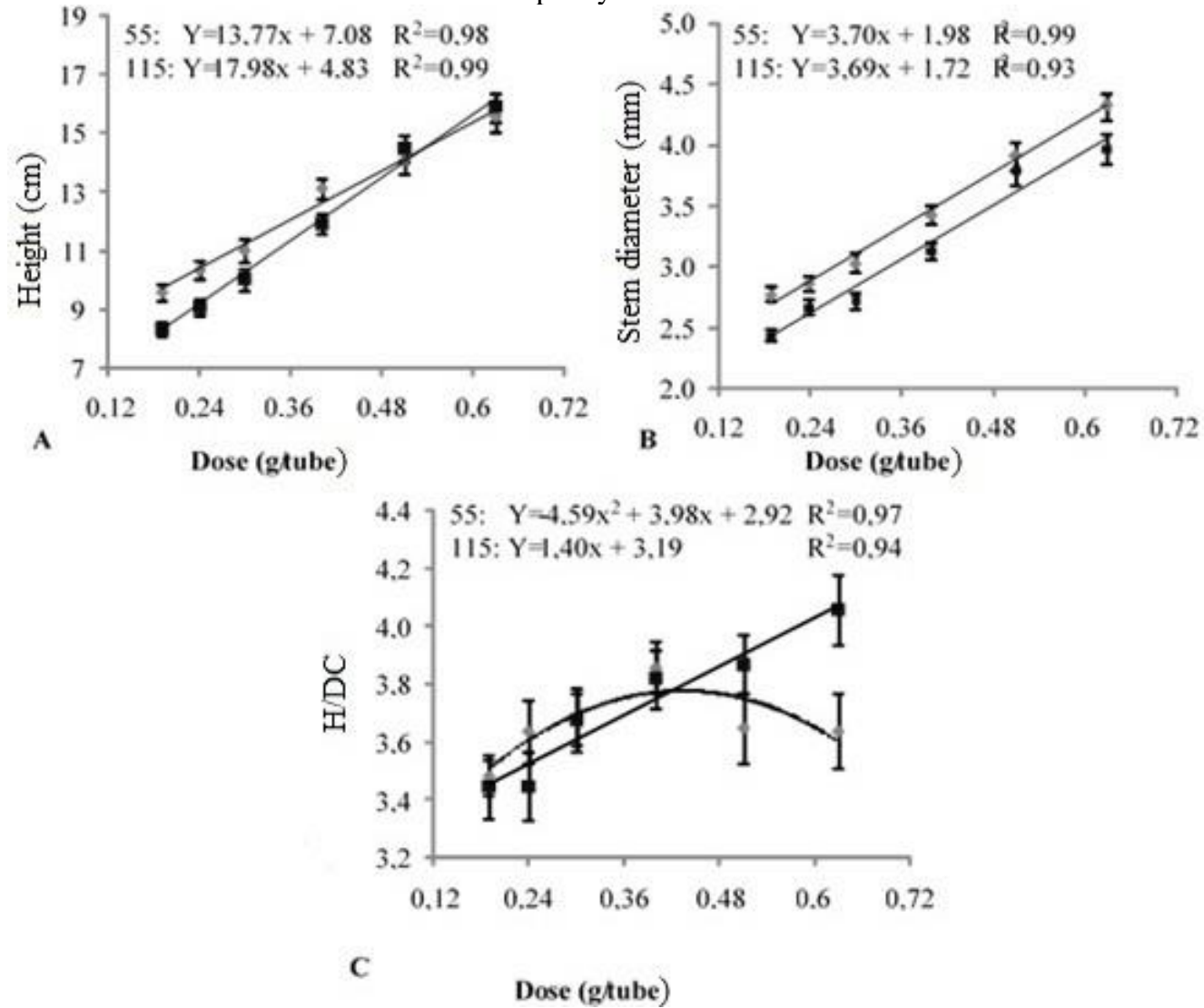

Figure 2. Effect of fertilizer, formulação15:09:12, dose per tube and tube volume in: A) height; B) diameter and;

C) height/diameter relation in Handroanthus ochraceus seedlings at 150 days after germination. 
Figura 2. Efeito da dose de fertilizante, formulação15:09:12, em função da capacidade volumétrica do tubete sobre a altura; diâmetro do coleto e relação altura/diâmetro do coleto, em mudas de Handroanthus ochraceus, aos 150 dias após a germinação
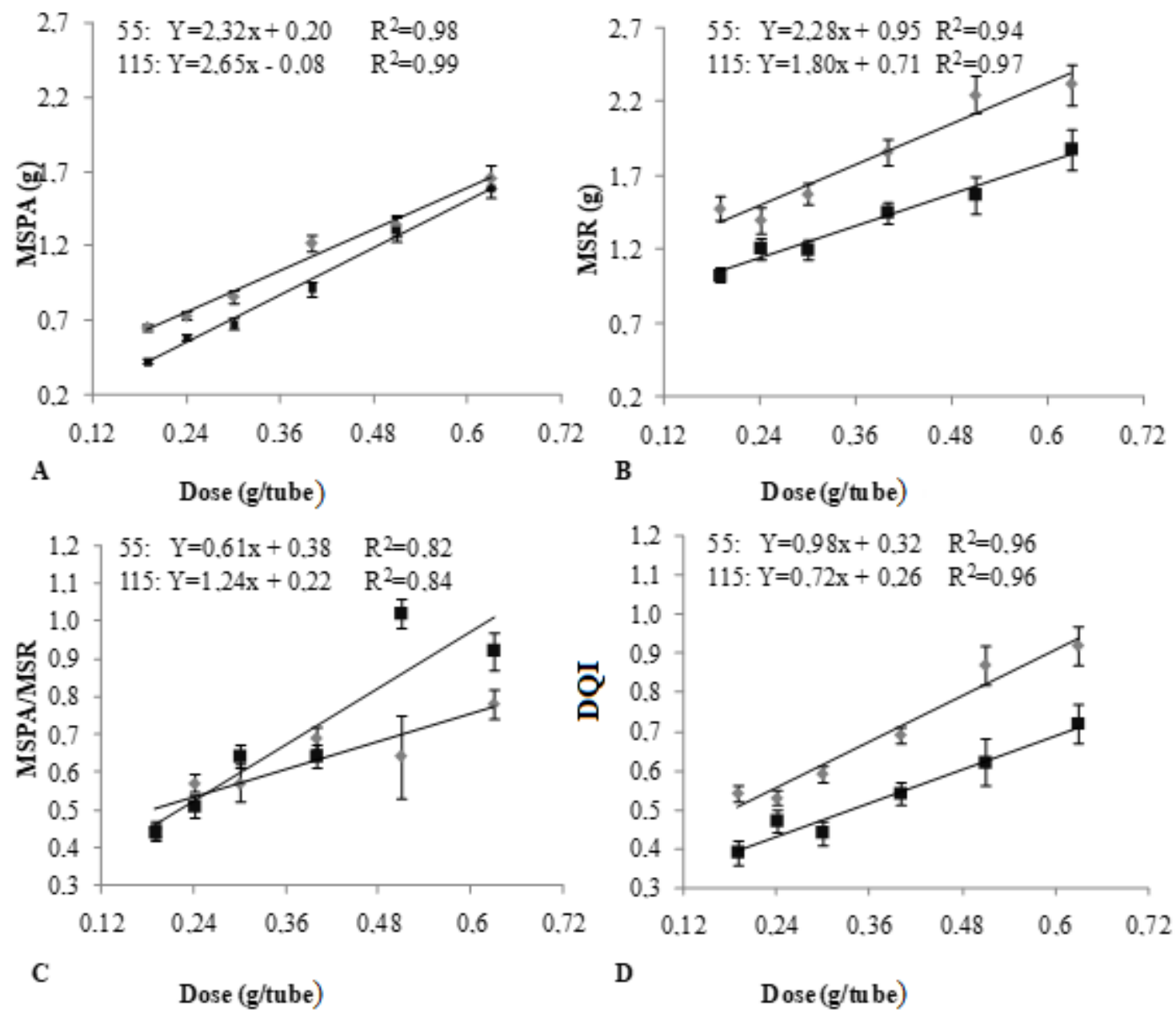

\section{$55 \mathrm{~cm}^{3} \quad 115 \mathrm{~cm}^{3}$}

Figure 3. Effect of fertilizer dose, formulation15: 09: 12, in Handroanthus ochraceus seedlings, 150 days after germination, depending on the volumetric capacity of the tube on: A) dry matter of shoot (MSPA); B) dry matter of root (MSR); C) dry matter of shoot/dry matter of root relation (MSPA/MSR) and; D) Dickson quality index (DQI).

Figura 3. Efeito da dose de fertilizante, formulação15:09:12, em mudas de Handroanthus ochraceus, aos 150 dias após a germinação, em função da capacidade volumétrica do tubete sobre: A) a matéria seca da parte aérea (MSPA); B) matéria seca das raízes (MSR); C) relação matéria seca da parte aérea/matéria seca das raízes (MSPA/MSR) e; D) índice de qualidade de Dickson (DQI).

\section{DISCUSSION}

The increase in the dose of fertilizers as a function of the volumetric capacity of the tube provides a linear rise in the increment in height and stem diameter at $150 \mathrm{DAG}$, as can be seen in figures $2 \mathrm{~A}$ and $2 \mathrm{~B}$. These facts could be explained by the two main laws in plant fertilization and nutrition. First, the Law of the minimum, the plant growth and production are limited by the nutrient in lesser availability. Second, by the Law of diminishing returns, the increasing doses of fertilizers enhance the seedling growth up to a maximum point. The rise in nutrient availability meets the minimum nutritional need of the plant and promotes an increase in the growth variables up to a maximum limit, bound by the expression of the Law of the minimum in which growth and production are limited by the nutrient in lesser availability. 
This effect was also observed by Freitas et al. (2017), in Cassia grandis seedlings with increased phosphorus fertilization, and by Cabreira et al. (2019), in Schizolobium parahyba seedlings under increasing doses of controlled-release fertilizers. We do not find the maximum point for the doses of fertilizers used in this work. For both growth characteristics, seedlings produced in tubes of $55 \mathrm{~cm}^{3}$ presented higher values than seedlings in containers of $115 \mathrm{~cm}^{3}$, highlighting the positive effect of the compensation of base fertilization on the growth characteristics of the seedlings.

The H/DC ratio of the seedlings of Handroanthus ochraceus showed differences regarding the tube's volume used (Figure $2 \mathrm{C}$ ). The results show that for the $115 \mathrm{~cm}^{3}$ containers, the H/DC ratio remained linear to the increase in the dose of fertilizer. These seedlings had an unbalanced increase in height to diameter, which can cause overturning and, in the most extreme case, etiolation. On the other hand, the H/DC ratio in the $55 \mathrm{~cm}^{3}$ tubes showed a negative quadratic behavior to the increase in the fertilizer dose with the highest fertilizer doses a more homogeneous H/DC in terms of the growth in height and stem diameter.

The H/DC relationship reflects the growth distribution in the seedling, with the lowest values being indicative of more balanced seedlings with greater chances of survival in the field, and the highest values represent unbalance, the risk of tipping over or etiolation (CARNEIRO, 1995). This relationship, however, must be carefully evaluated since to express the quality of the seedling, the height and diameter values must be within an acceptable standard. Therefore, based on Figure $2 \mathrm{C}$, seedlings produced in $55 \mathrm{~cm}^{3}$ tubes present a better balance between $\mathrm{H}$ and DC as the doses of fertilizer per container were increased as compared to seedlings on $115 \mathrm{~cm}^{3} \mathrm{containers}$

The increase in fertilizer doses led to a rise of MSPA, MSR, MSPA/MSR, and DQI in seedlings produced in tubes of 55 and $115 \mathrm{~cm}^{3}$, as shown in Figure 3. According to the law of the minimum, with the increase in nutrient availability, biomass accumulation was expected, being limited by the law of diminishing returns, the maximum growth point according to the applied dose. The biomass accumulation and better quality of seedlings as the increase in fertilizer doses were also observed by Dutra et al. (2017), Leite et al. (2017), and Goulart et al. (2017). The comparison between container volumes, biomass accumulation, and quality reveals that seedlings produced in $55 \mathrm{~cm}^{3}$ tubes were superior to those produced in $115 \mathrm{~cm}^{3}$ when using the compensation of base fertilization

The MSPA/MSR ratio (Figure 3C) reveals that seedlings produced in tubes of $115 \mathrm{~cm}^{3}$ and under higher doses of fertilizer per container present higher values than those found in seedlings in smaller containers. This fact is a result of the lower root biomass accumulation in $115 \mathrm{~cm}^{3}$ tubes, augmenting the relationship between MSPA/MSR in consequence. This species has an unusual MSPA/MSR ratio, with a greater accumulation of biomass in the root system compared to shoots, resulting, therefore, with MSPA/MSR ratios below one. This behavior is typical of Cerrado plants, which have tuberous and thick roots, being a response to environmental conditions where plants accumulate most of the reserves in the roots either to explore larger volumes of soil or for greater resilience against damage caused by fire. Such behavior was also observed in Amburana cearenses and Spondias tuberosa by Oliveira et al. (2019). Seedlings produced in $55 \mathrm{~cm}^{3}$ tubes present a good growth balance since even if there is a greater increase with increasing doses of fertilizer, the relationship between growth characteristics (MSPA/MSR) varied less when compared to the seedlings produced in $115 \mathrm{~cm}^{3}$ tubes.

The DQI (3D FIGURE) presented a relation, the higher the fertilizer dosage per container used, the higher was the DQI for the seedlings of Handroanthus ochraceus. Likewise, it turns out that the size of the container also interferes significantly. Seedlings produced in tubes of $55 \mathrm{~cm}^{3}$ presented higher DQI than those grown of $115 \mathrm{~cm}^{3}$ when compared to equal fertilizer dosages. Thus, the DQI proves to be efficient in expressing the quality of the seedlings of Handroanthus ochraceus since its results convened all the results obtained by each of the characteristics analyzed separately.

Thus, keeping the conditions established in this work, it is possible that the production of seedlings of Handroanthus ochraceus in tubes with smaller volumetric capacity can be identical or superior to those with greater volumetric capacity, as long as there is nutritional compensation. Therefore, nutritional compensation is an efficient method to isolate nutritional variation in seedling production, being, therefore, efficient for comparative studies of different volumes of containers.

\section{CONCLUSIONS}

- Compensation of base fertilization proved to be adequate to isolate the effect of volumetric capacity in polypropylene tubes of $55 \mathrm{~cm}^{3}$ and $115 \mathrm{~cm}^{3}$.

\section{REFERENCES}

ABREU, A. H. M. et al. Caracterização e potencial de substratos formulados com biossólido na produção de mudas de Schinus terebinthifolius Raddi. e Handroanthus heptaphyllus (Vell.) Mattos. Ciência Florestal, Santa Maria, v. 27, n. 4, p. 1179-1190, 2017. 
ALMEIDA, R. S. et al. Crescimento e qualidade de mudas de Croton floribundus Spreng. em diferentes recipientes e substratos. Enciclopédia Biosfera, Jandaia, v. 10, n. 19, p. 672-685, 2014.

BRACHTVOGEL, E. L.; MALAVASI, U. C. Volume do tubete, adubação e sua forma de mistura ao substrato no crescimento inicial de Peltophorum dubium (Sprengel) Taubert em viveiro. Revista Árvore, Viçosa, v. 34, n. 2, p. 223-232, 2010.

CABREIRA, G. V. et al. Fertilização e recipientes na produção de mudas e sobrevivência pós plantio de Schizolobium parahyba. Ciência Florestal, Santa Maria, v. 29, n. 4, p. 1644-1657, 2019.

CARNEIRO, J. G. A. Produção e controle de qualidade de mudas florestais. Curitiba: UFPR, 1995.

CUNHA, A. O. et al. Efeitos de substratos e das dimensões dos recipientes na qualidade das mudas de Tabebuia impetiginosa (Mart. Ex DC) Standl. Revista Árvore, Viçosa, v. 29, n. 4, p. 507-516, 2005.

DANTAS, A. A. A.; CARVALHO, L. G.; FERREIRA, E. Classificação e tendências climáticas em Lavras, MG. Ciência e Agrotecnologia, Lavras, v. 31, n. 6, p. 1862-1866, 2007.

DAVIDE, A. C.; FARIA, J. M. R. Viveiros florestais. In: DAVIDE, A. C.; SILVA, E. A. A. (Ed.). Produção de sementes e mudas de espécies florestais. Lavras: UFLA, 2008. p. 83-122.

DUTRA, T. R. et al. Fertilizante de liberação lenta no crescimento e qualidade de mudas de canafístula (Peltophorum dubium (Spreng.) Taub.). Floresta, Curitiba, v. 46, n. 4, p. 491-498, 2017.

FERRARI, M. et al. Influência de fertilizante de liberação controlada em mudas de Tabernaemontana catharinensis. Pesquisa Florestal Brasileira, Colombo, v. 36, n. 88, p. 543-547, 2016.

FIGUEIRÓ, C. G. et al. Efeito do recipiente e do método de superação de dormência no crescimento de mudas de Schizolobium parahyba (Vell.) SF Blake. Enciclopédia Biosfera, Jandaia, v. 14, n. 25, p. 490-497, 2017.

FREITAS, E. C. S. de et al. Crescimento e qualidade de mudas de Cassia grandis Linnaeus f. em resposta à adubação fosfatada e calagem. Ciência Florestal, Santa Maria, v. 27, n. 2, p. 509-519, 2017.

GOMES, J. M.; PAIVA, H. N. Viveiros Florestais: propagação sexuada. 1. ed. Viçosa: UFV, 2011. 116p.

GOULART, L. M. L. et al. Produção de mudas de ipê-amarelo (Tabebuia serratifolia) em resposta a fertilização nitrogenada. Floresta Ambiente, Seropédica, v. 24, 2017.

LEITE, T. S. et al. Produção de mudas de Enterolobium contortisiliquum e partição de assimilados em resposta à adubação fosfatada e inoculação com fungos micorrízicos. Ciência Florestal, Santa Maria, v. 27, n. 4, p. 11571166, 2017.

LIMA FILHO, P. et al. Produção de mudas de Ceiba speciosa em diferentes volumes de tubetes utilizando o biossólido como substrato. Ciência Florestal, Santa Maria, v. 29, n. 1, p. 27-39, 2019.

LORENZI, H. Árvores brasileiras: manual de identificação e cultivo de plantas arbóreas nativas do Brasil. 4. ed. Nova Odessa: Plantarum, 2002.

MELO, L. A. et al. Qualidade e crescimento inicial de mudas de Mimosa caesalpiniifolia Benth. produzidas em diferentes volumes de recipientes. Ciência Florestal, Santa Maria, v. 28, n. 1, p. 47-55, 2018.

MEWS, C. L. et al. Effect of hydrogel and urea on the seedling production of Handroanthus ochraceus (Cham.) Mattos. Floresta e Ambiente, Seropédica, v. 22, n. 1, p. 107-116, 2015.

NAVROSKI, M. C. et al. Procedência e adubação no crescimento inicial de mudas de cedro. Pesquisa florestal brasileira, Colombo, v. 36, n. 85, p. 17-24, 2016.

OLIVEIRA, M. M. et al. Crescimento e partição de massa seca em plantas jovens de amburana (Amburana cearensis (Fr. All.) AC Smith) e de umbuzeiro (Spondias tuberosa Arr. Cam.). Ciência Florestal, Santa Maria, v. 29, n. 3, p. 1142-1153, 2019.

SABINO, M. et al. Crescimento de mudas de ipês em diferentes telas de sombreamento. Nativa, Sinop, v. 4, n. 2, p. 61-65, 2016.

SILVA, R. R. et al. Qualidade de mudas de Copaifera langsdorffii Desf., cultivadas em substratos alternativos, em função de adubação complementar. Colloquium Agrariae, Presidente Prudente, v. 15, n. 5, p. 67-76, 2019.

VIEIRA, C. R. et al. Análise de correlação canônica entre crescimento e nutrição em mudas de Teca. Floresta e Ambiente, Seropédica, v. 26, n.2, 2019. 